Tohoku J. Exp. Med., 2003, 200, 211-229

\title{
A Novel GT-Mismatch Binding Protein That Recognizes Strict DNA Sequences with High Affinity
}

Maki Takata-Yahiro, Yoshito Fujil, Jorge Fraga Nodarse, Mohammed Rafiqul Islam, Shinya Oda, ${ }^{1}$ Qiu-Mei Zhang, ${ }^{2}$ Shuji Yonei $^{2}$ and Michio NAKAMURA

Department of Host-Defense Biochemistry, Institute of Tropical Medicine, Nagasaki University, Nagasaki 852-8523,

${ }^{1}$ Institute for Clinical Research, National Kyushu Cancer Center, Fukuoka 8111395, and

${ }^{2}$ Laboratory of Radiation Biology, Graduate School of Science, Kyoto University, Kyoto 606-8502

Takata-Yahiro, M., Fujil, Y., Nodarse, J.F., Islam, M.R., Oda, S., Zhang, Q.-M., Yonei, S. and Nakamura, M. A Novel GT-Mismatch Binding Protein that Recognizes Strict DNA Sequences with High Affinity. Tohoku J. Exp. Med., 2003, 200 (4), 211-229 — Mismatched or damaged base pairs in DNA are mutagenic and both eukaryotes and prokaryotes have a series of repair systems that decrease a spontaneous mutation rate. All exocyclic amino groups of cytosine $(\mathrm{C})$, adenine $(A)$, and guanine $(G)$ contribute to hydrogen bonds for base pairing. High temperature and oxidative stresses increase the deamination of these bases and methylated C. These deaminated sites would be initially recognized by components of DNA repair system. We discovered a novel G/thymine(T)-mismatch binding protein (nGTBP) that bound, with high affinity, to a minimal 14-mer DNA heteroduplex with a strict 5'-TRTGNB-3' sequence ( $\mathrm{R}$ for purine, $\mathrm{N}$ for any bases, and B for "not A," namely for $\mathrm{C}, \mathrm{G}$, or $\mathrm{T}$ ). This italicized $\mathrm{G}$ position mismatched with $\mathrm{T}$ could be replaced by hypoxanthine, the deaminated A. The nGTBP, however, barely recognized DNA duplexes individually containing 8-oxo-G, thymine glycol, and 5-methylcytosine._— GT-mismatch binding protein; DNA repair; deamination; gp91 ${ }^{\text {phox }}$ promoter

(C) 2003 Tohoku University Medical Press

Received June 4, 2003; revision accepted for publication August 22, 2003.

Address for reprints: Michio Nakamura, M.D., Ph.D., Department of Host-Defense Biochemistry, Institute of Tropical Medicine, Nagasaki University, 1-12-4 Sakamoto, Nagasaki 852-8523, Japan.

e-mail: nakamura@ net.nagasaki-u.ac.jp 
DNA and nucleotides are exposed to various chemical and physical stresses that modify base structures and cause mutations such as single-base substitutions (Lindahl and Wood 1999). Prokaryotes and eukaryotes have various systems for excising and correcting mispaired or unpaired bases and/or nucleotides generated under these stresses to decrease their mutation frequencies by $3-5$ orders of magnitude (Marti et al. 2002). Bases and base pairs deviating from the standard Watson-Crick model are recognized by various proteins involved in the base excision repair system such as a mismatch-specific thymine-DNA glycosylase (TDG) (Neddermann et al. 1996) and MutS $\alpha$ (Kolodner 1996) involved in long-patch mismatch repair. In addition to depurination/ depyrimidination and methylation, deamination is a common cause of spontaneous damage to DNA bases (Kow 2002). In contrast to the activation-induced cytidine deaminase-catalized deamination of DNA bases which contributes to the somatic hypermutation in B cells (PetersenMahrt et al. 2002), non-enzymatic deamination of any bases is harmful because it alters the hydrogen donating amino groups to hydrogen accepting keto groups. Deamination rates of cytosine $(\mathrm{C})$ and adenine $(\mathrm{A})$ in a human genome were estimated to be about 500 and $>50$ a day, respectively (Lindahl 1993). Deaminated DNA bases are surveyed mainly by base excision repair enzymes including members of the uracilDNA glycosylase (UDG) family such as TDG (Neddermann and Jiricny 1994) and a UDG (Krokan et al. 2002), and by long-patch mismatch repair systems such as MutS (Cox et al. 1972) and MutS homologs (MSHs) (Leach et al. 1993). These deamination site-recognizing proteins have, in general, a loose selectivity against damaged base pairs and their neighboring sequences (Singer and Hang 2000) with exceptions of UDG strictly requiring a uracil (U), namely deaminated $\mathrm{C}$, as the damaged base (Mol et al. 1995) and guanine $(\mathrm{G}) /$ thymine (T)mismatch recognizing $\mathrm{N}$-glycosylases preferen- tially requiring a $\mathrm{C} / \mathrm{G}$ pair $5^{\prime}$ to the mismatched $\mathrm{G} / \mathrm{T}$ in $\mathrm{CpG}$ sequences (Lari et al. 2002). Deamination of DNA is increased by reactive oxygen- and nitrogen derivatives (Burney et al. 1999) and under high temperature (Ehlrich et al. 1986), which is mutagenic and is considered to have promoted evolution (Karran and Lindahl 1980; Reanney and Pressing 1984). High temperature may be an oncogenic factor to evoke esophageal squamous carcinoma common in people having a habit of drinking hot meals in South America (Putz et al. 2002). We discovered a novel G/T mismatch-binding protein that specifically recognizes DNA sequences containing a TRTXNB element ( $\mathrm{R}$ for purine, $\mathrm{N}$ for any bases, and B for "not A," namely for C, G, or $\mathrm{T}$ ) where $\mathrm{X}$ is $\mathrm{G}$ or hypoxanthine (Hx), but not 8-oxoguanine (oG), paired with $\mathrm{T}$. Because of its strong binding and restriction to the above-mentioned specific DNA element, we propose it to be a new candidate for deaminated-base-specific DNA binding proteins, but not oxidized-base-specific DNA binding proteins.

\section{MATERIALs AND MeTHods}

\section{Preparation of nuclear extracts}

Nuclear extracts were prepared from cells as described previously (Suzuki et al. 1998). Approximately $1 \times 10^{7}$ HL-60-C-15 cells were swollen in $400 \mu$ l of ice-cold buffer A $(10 \mathrm{mM}$ Hepes- $\mathrm{HCl}$ buffer [pH 7.9] containing $10 \mathrm{mM}$ $\mathrm{KCl}, \quad 0.1 \mathrm{mM}$ EGTA, $0.1 \mathrm{mM}$ EDTA, $1 \mathrm{mM}$ dithiothreitol [DTT], $0.5 \mathrm{mM}$ phenylmethylsulfonyl fluoride [PMSF, Sigma, St. Louis, MO, USA]), and Complete ${ }^{\mathrm{TM}}$ Protease Inhibitor Mixture (Roche Diagnostics K.K., Tokyo). After a 15 -minutes incubation at $4^{\circ} \mathrm{C}$, the cells were lysed with $0.6 \%$ Nonidet P-40 and vortexed vigorously for 10 seconds. Supernatants were removed from the lysates by centrifugation $(12000 \times g$, 30 seconds), and precipitates rich in nuclei were suspended in $100 \mu$ l of icecold buffer C (20 mM Hepes-HCl buffer [pH 7.9] containing $0.4 \mathrm{M} \mathrm{NaCl}, 1 \mathrm{mM}$ EGTA, $1 \mathrm{mM}$ 
EDTA, $1 \mathrm{mM}$ DTT, and $1 \mathrm{mM} \mathrm{PMSF/Com-}$ plete $^{\mathrm{TM}}$ Protease Inhibitor Mixture). Nuclear extracts were separated by centrifugation $\left(12000 \times g\right.$ at $4^{\circ} \mathrm{C}$ for 5 minutes) and stored in aliquots at $-80^{\circ} \mathrm{C}$. Protein concentration was determined with the Bio-Rad protein assay kit.

Electrophoretic mobility shift assays and Scatchard plots

In all Electrophoretic mobility shift assays (EMSA) experiments except for one shown in Fig. 2, either one of the upper and lower strands was radiolabeled with ${ }^{32} \mathrm{P}$ as reported previously (Yang et al. 2000) and annealed with 3-10 times excess cold counterpart oligomer for making each probe. The principal sequence of probes and competitors is identical to the sequence of the human gp91 $91^{\text {phox }}$ promoter spanning from base pair (bp) -189 to bp -167 and a G/T-mismatch was usually introduced to bp 177 which corresponds to the position 477243 of The Human Genome Database NT_011568 (8gi: 29801784) (Fig. 1). EMSA was performed as described previously (Suzuki et al. 1998). Each reaction mixture $(20 \mu \mathrm{l})$ containing the following constituents was incubated on ice for 15 minutes; $0.1-24 \mu \mathrm{g}$ of nuclear extract protein, each radiolabeled probe equivalent to $3.3 \mathrm{fmol}$,
$0-0.05 \mu \mathrm{g}$ of poly(dI-dC)/poly(dI-dC) (Amersham Biosciences KK, Tokyo), $50 \mathrm{mM} \mathrm{KCl}, 1 \mathrm{mM}$ $\mathrm{MgCl}_{2}, 1 \mathrm{mM}$ DTT, $0.2 \mathrm{mM}$ EDTA, $0.01 \%$ Triton X-100, 5\% glycerol, and $0.5 \mathrm{mM}$ spermidine in $20 \mathrm{mM}$ Hepes buffer (pH 7.9). In competition assays, a 100-fold molar excess of unlabeled competitor oligonucleotides was added prior to the addition of the probe to the mixture, which was then preincubated on ice for 15 minutes. To undertake an inhibition assay using antibodies, an aliquot of nuclear extracts was preincubated on ice with one of the following IgG preparations (each $2-4 \mu \mathrm{g}$ ) for 1 hour before the addition of the probe; rabbit polyclonal IgG raised against human AML- $1 \alpha$, rabbit polyclonal IgG raised against $\mathrm{CBF} \beta$ (both from Oncogene Research Products, Cambridge, MA, USA), goat polyclonal IgG raised against human GT-mismatch binding protein (GTBP, also called human MutS $\alpha$ homolog protein 6 [hMSH6]), control goat IgG, and control rabbit IgG (all the rest from Santa Cruz Biotechnology, Santa Cruz, CA, USA). Electrophoresis was performed on a $3.4-5.0 \%$ polyacrylamide gel in $0.4 \times$ TBE buffer $(\mathrm{pH} 8.3)$ containing $36 \mathrm{mM}$ Tris-borate and $8 \mathrm{mM}$ EDTA at $4^{\circ} \mathrm{C}$ to avoid the enzymatic degradation of probes. Upperstrand sequences of typical probes and competi-

\title{
Wt
}

$$
\begin{array}{ll}
(\text { gp91 }-189 \sim-167) & \text { CCCTTTTTTTGT (A) GTTGTTGAGG } \\
-177 G / T & \\
(\text { gp91 }-189 \sim-167) & \text { CCCTTTTTTTGT }(G) \text { GTTGTTGAGG }
\end{array}
$$

\section{CCCTTTTTTTGT ( $G$ ) GTTGTTGAGG}

AML site

\author{
CGAGTATTGT ( $\underline{\text { G }})$ GTTAATACG
}

\section{MutS $\alpha$ site AATTCCCGGgGATCCGTC ( $\underline{G})$ ACCTGCAGCCAAGCT}

\section{TDG site}

\section{AGCTTGGCTGCAGGC ( $(\boldsymbol{G})$ GACGGATCCCCGGGAATT}

Fig. 1. Upper strand base sequences (5' to $3^{\prime}$ directions) of deoxyribonucleotide oligomers used. $\mathrm{Wt}$ is the original gp91 ${ }^{\text {phox }}$ promoter sequence spanning from bp -189 to bp -167 . Italicized $\mathrm{G}$ in parentheses were usually mispaired with $\mathrm{T}$ in the following experiments. References for consensus site sequences of oligomers are Meyers et al. (1993), Nakajima et al. (1999), and Waters et al. (1999) for AML site, MutS $\alpha$ site, and TDG site, respectively. 


\section{Probe Wt}

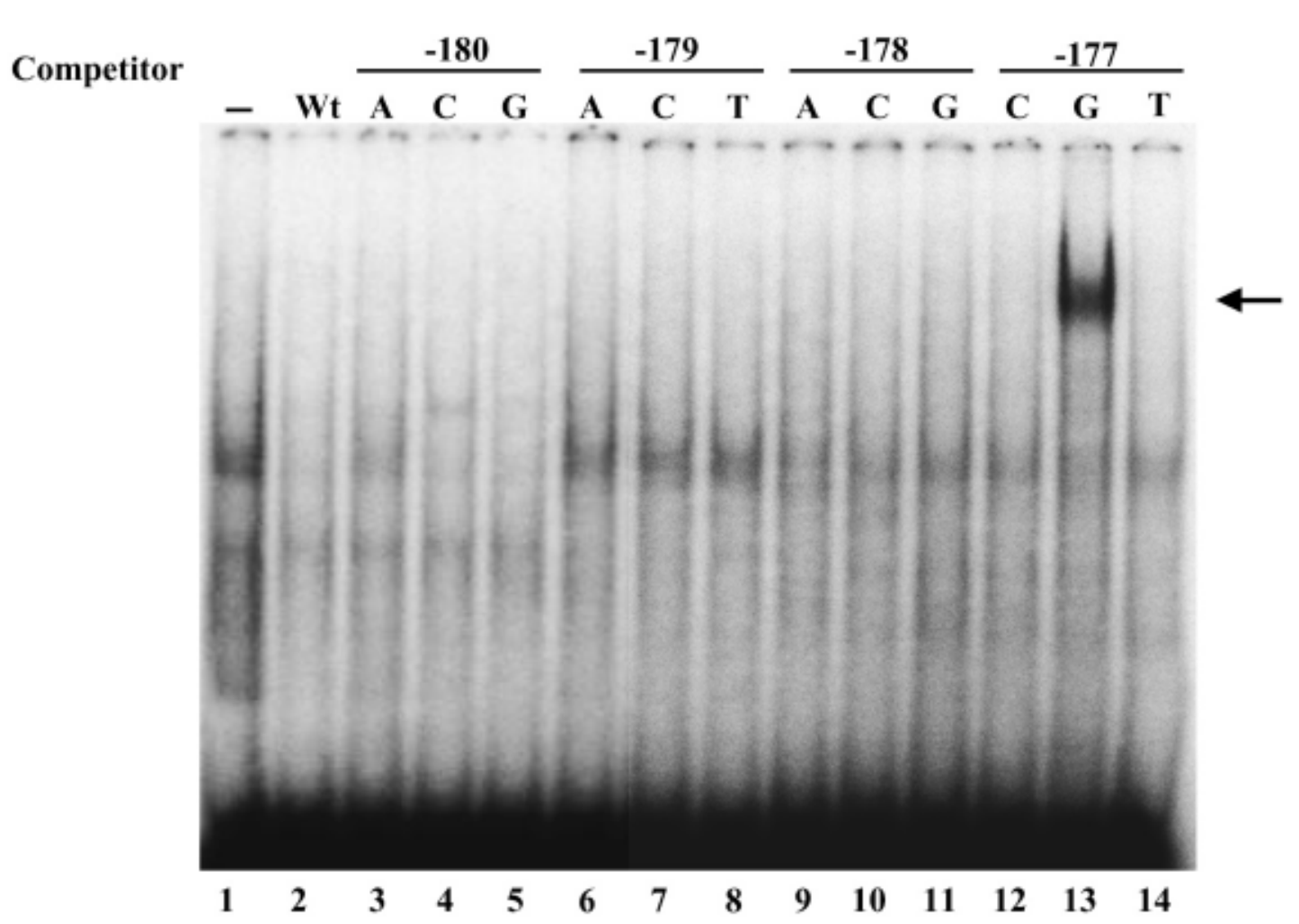

Fig. 2. Appearance of an unexpectedly super-shifted band in a competition assay for shifted bands using EMSA. Wild-type 23-mer of gp91 ${ }^{\text {phox }}$ promoter "homoduplex" was ${ }^{32} \mathrm{P}$-labeled at both ends and used as the probe. Only the competitor with a G/C pair at bp -177 exhibited a strong super-shifted band (lane 13) shown by an arrow. A few bands were detected which can be specifically inhibited by the wild-type competitor (compare lanes 1 and 2). Nuclear extracts were obtained from HL-60-C-15.

tors are shown in Fig. 1. Each italicized G was usually mismatched with a $\mathrm{T}$ of the corresponding lower strand, or replaced by an Hx. All these intact oligomers and insertion/deletion oligomers were purchased from Hokkaido System Sciences. Most oligomers containing modified bases or abasic sites were purchased from Proligo Japan KK (Kyoto). A 14-mer lower strand oligomer containing a thymine glycol (Tg) (5'-CAACAACTgACAAAA-3') was made as described previously (Miyabe et al. 2002).

Apparent dissociation constants (Kd) were determined as reported previously (Yang et al. 2000). The binding and running conditions were same as those described above. Each fixed amount of nuclear protein extract from HL-60-C-15 cells was incubated on ice with a serially diluted labeled probe and incubated for 15 minutes which was confirmed to be long enough to bring the reaction to an equilibrium. Free and bound DNA were counted from a figure linearly imaged on Molecular Imager FX (Bio-Rad). Scatchard plots were accomplished assuming front counts and specifically retarded counts to be proportional to free and bound concentrations, respectively, and also assuming that one protein molecule binds to one DNA heteroduplex. 


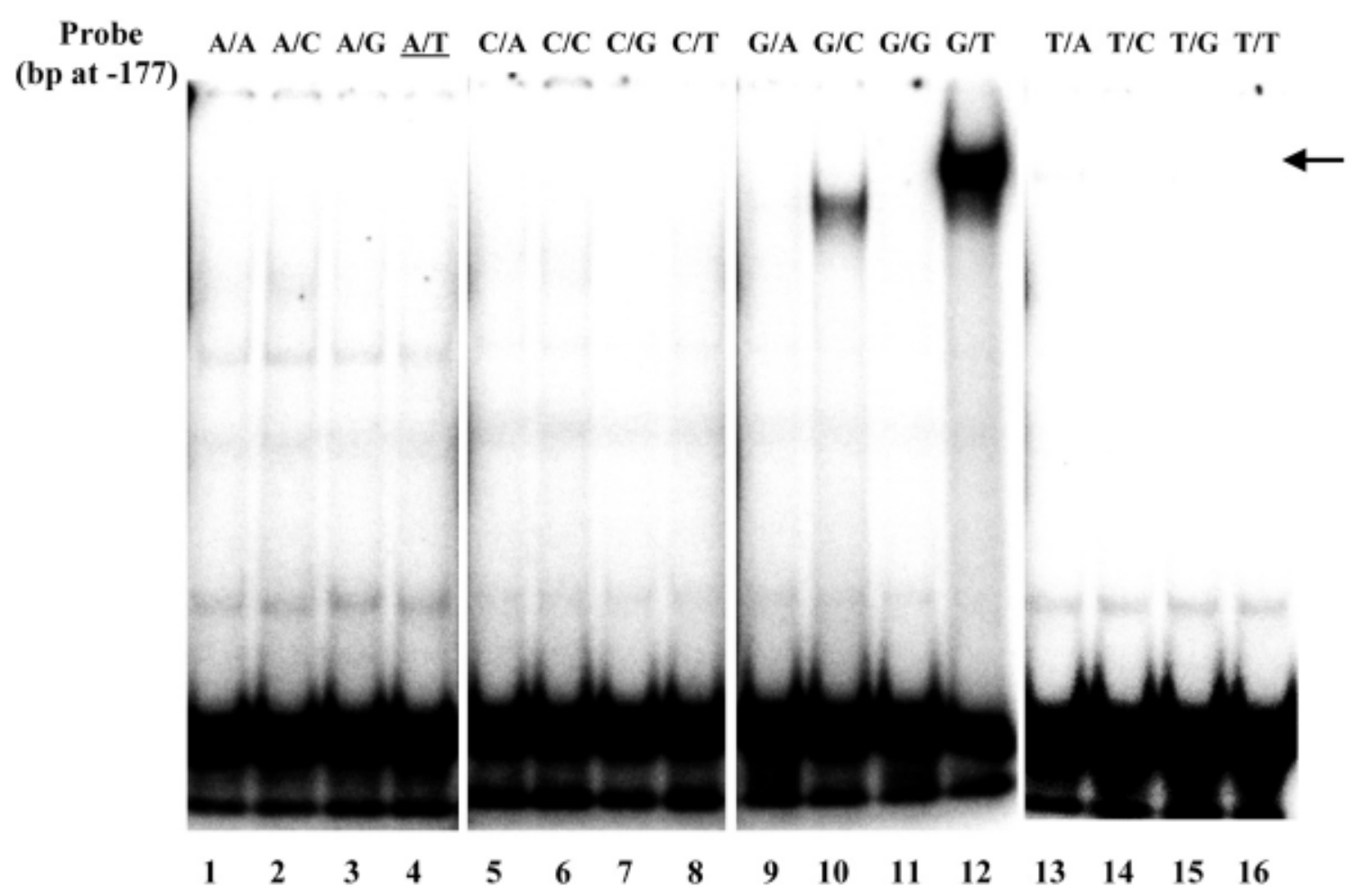

Fig. 3. Demonstration of a bp $-177 \mathrm{G} / \mathrm{T}$ mismatch-specific DNA binding protein. Only the 23-mer probe with a G/T-mismatch at bp -177 exhibited a strong shifted band (nGTBP band indicated by an arrow at lane 12) corresponding to the unexpectedly super-shifted band shown in Fig. 2. The significant band shown in lane 10 may be due to CBF $\beta$.

\section{RESULTS AND DISCUSSION}

A mismatched G/T pair is the only pair that makes a "super-shifted" band with a gp91 phox promoter probe

In the process of defining the base specificity for the binding of a protein from HL-60-C-15 cell nuclear extracts to a gp91 ${ }^{\text {phox }}$ promoter fragment spanning from bp -189 to bp -167 (Fig. 1, Wt), we carried out competition assays by EMSA of various homoduplexes with single point mutations. As shown in Fig. 2, the homoduplex competitor with $\mathrm{G}$ at bp -177 (177G/C 23-mer homoduplex) generated a strong "super-shifted" band (the arrowed band in lane 13) in contrast to the remaining homoduplex competitors. As usually expected, some competitors specifically blocked shifted bands as observed with the wild-type competitor (compare lanes 2, 4, and 5 with lane 1). The super- shifted band was not always reproduced well and was not observed when an upper strandlabeled Wt $-177 \mathrm{~A} / \mathrm{T}$ 23-mer probe was used. Accordingly, the super-shifted band was not due to the association of the probe/probe-binding protein complex with the competitor/ competitor-binding protein complex (data not shown). After several trial and error studies, we suspected that the band was due to a newly paired probe with a mismatched $\mathrm{G} / \mathrm{T}$ at bp 177.

We then systematically introduced all possible 16 pairs into bp -177 of this 23 -mer probe (Fig. 3) to find the specific base pair required for this super-shift-making factor(s). We could demonstrate a significant band at the expected position only when the probe had the mismatched G/T pair at bp -177 (lane 12), and the band was exceptionally strong. This band was not detected if the nuclear extracts had been 
treated with V8 protease or boiled for 5 minutes (data not shown), indicating the factor(s) to be a protein(s). Hereafter, we tentatively call the band and its constituent protein, a novel GTmismatch binding protein band (nGTBP band) and a novel GT-mismatch binding protein (nGTBP), respectively. A weakly expressed band traveling faster than the nGTBP band was observed when a matched $\mathrm{G} / \mathrm{C}$ probe was used (lane 10). The most likely DNA-binding protein responsible for this weakly expressed band is a heterodimer of core binding factors $(\mathrm{CBF})$ because the probe has a TGTGGT sequence which is completely matched to the core element for AML-1 $\alpha$ (AML site in Fig. 1, Meyers et al. 1993). $n G T B P$ is present in various mammalian cell lines and tissues, and different from various $G$ / T-mismatch recognizing proteins

In order to find the cellular distribution of nGTBP, we examined nuclear extracts obtained from various mammalian cell lines and murine tissues, and showed results in part in Fig. 4. The nGTBP band was always observed regardless of the origin of the nuclear extracts including LoVo and DLD-1 (lanes 1, 4, 7, and 10). The nGTBP band was also demonstrated using EMSA for the nuclear extracts of murine brain, liver, and kidney (data not shown). Therefore, nGTBP is expected to be common in various tissues, suggesting that its role is important for

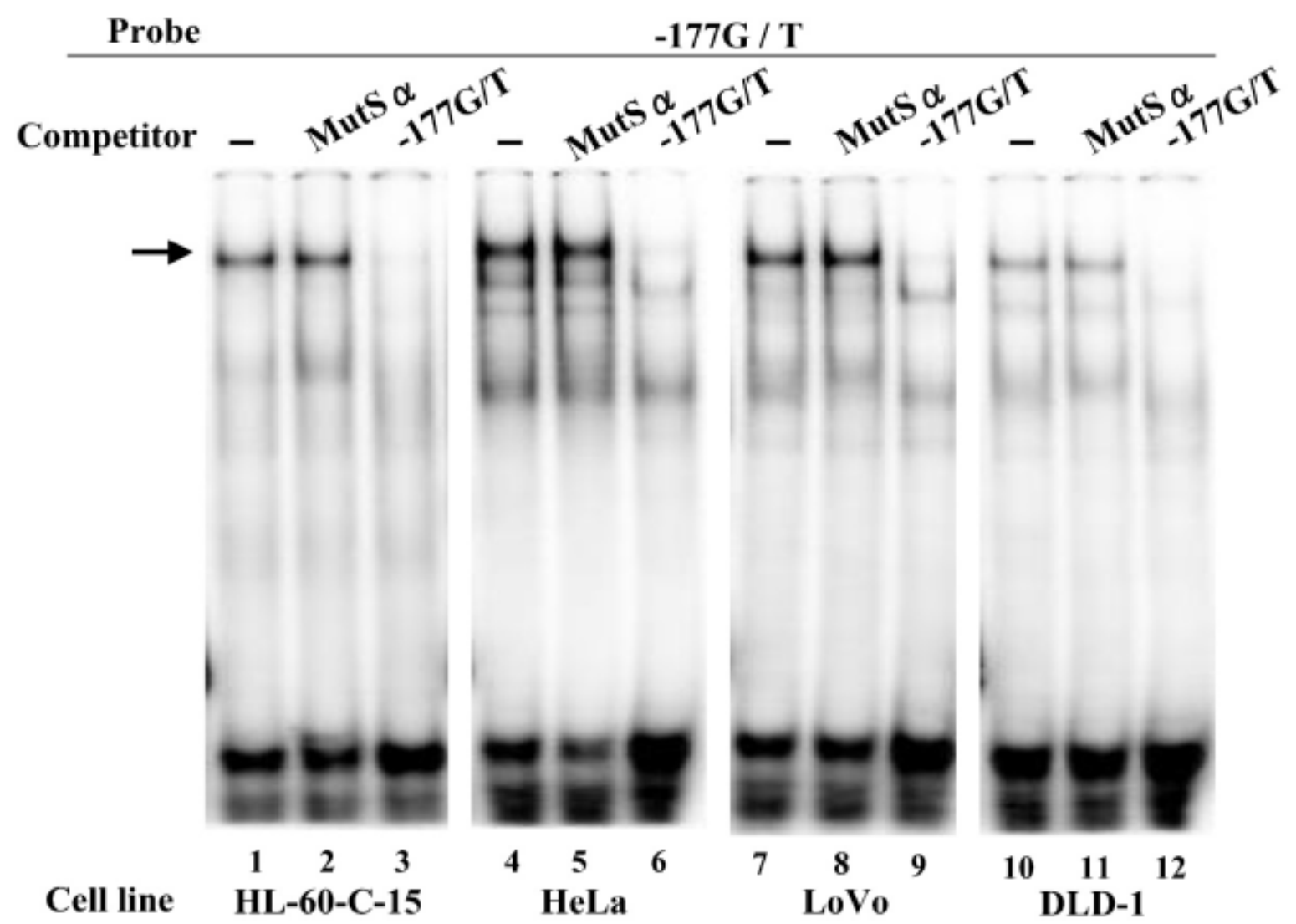

Fig. 4. nGTBP is present in various cell lines and differs from hMutS $\alpha$ (hMSH2/hMSH6). nGTBP bands indicated by an arrow are always demonstrated in nuclear extracts obtained from various cell lines as designated at the bottom line using EMSA with - 177G/T 23-mer heteroduplex as the probe. LoVo and DLD-1 are deficient in hMSH2 and/or hMSH6. The nGTBP bands shown by an arrow are resistant to MutS $\alpha$ site-containing competitor (lanes $2,5,8$, and 11 ) but not to $-177 \mathrm{G} / \mathrm{T}$ competitor (lanes $3,6,9$, and 12 ). 
life. LoVo and DLD-1 lacking components of hMSH2 and/or hMSH6 for human MutS $\alpha$ homolog (Malkhosyan et al. 1996) significantly expressed nGTBP, suggesting this nGTBP to be different from these hMSH components. It was supported by the ineffectiveness of a MutS $\alpha$ site competitor heteroduplex on the nGTBP band (lanes 2, 5, 8, and 11). The ineffectiveness of the competitor was reproduced by the nGTBP band shown in the lane 4 (nGTBP upper arrow) of Fig. 5 for which EMSA had been carried out in the absence of poly $(\mathrm{dI}-\mathrm{dC}) /$ poly(dI-dC) nonspecific competitor to simultane- ously demonstrate both the nGTBP band and an hMutS $\alpha$ band indicated by the lower arrow accompanied with GTBP. The competitor was active because it specifically abrogated this fast shifted band that could be disrupted by a specific antibody against MSH6, a subunit of hMutS $\alpha$ (lane 8), but not by a specific antibody against human $\mathrm{CBF} \quad \beta$ subunit (lane 9). Furthermore, the antibody against MSH6 did not abrogate the nGTBP band at all (lane 8), indicating that the band contains a GTmismatch binding protein different from MSH6. In contrast to the preceding EMSA condi-

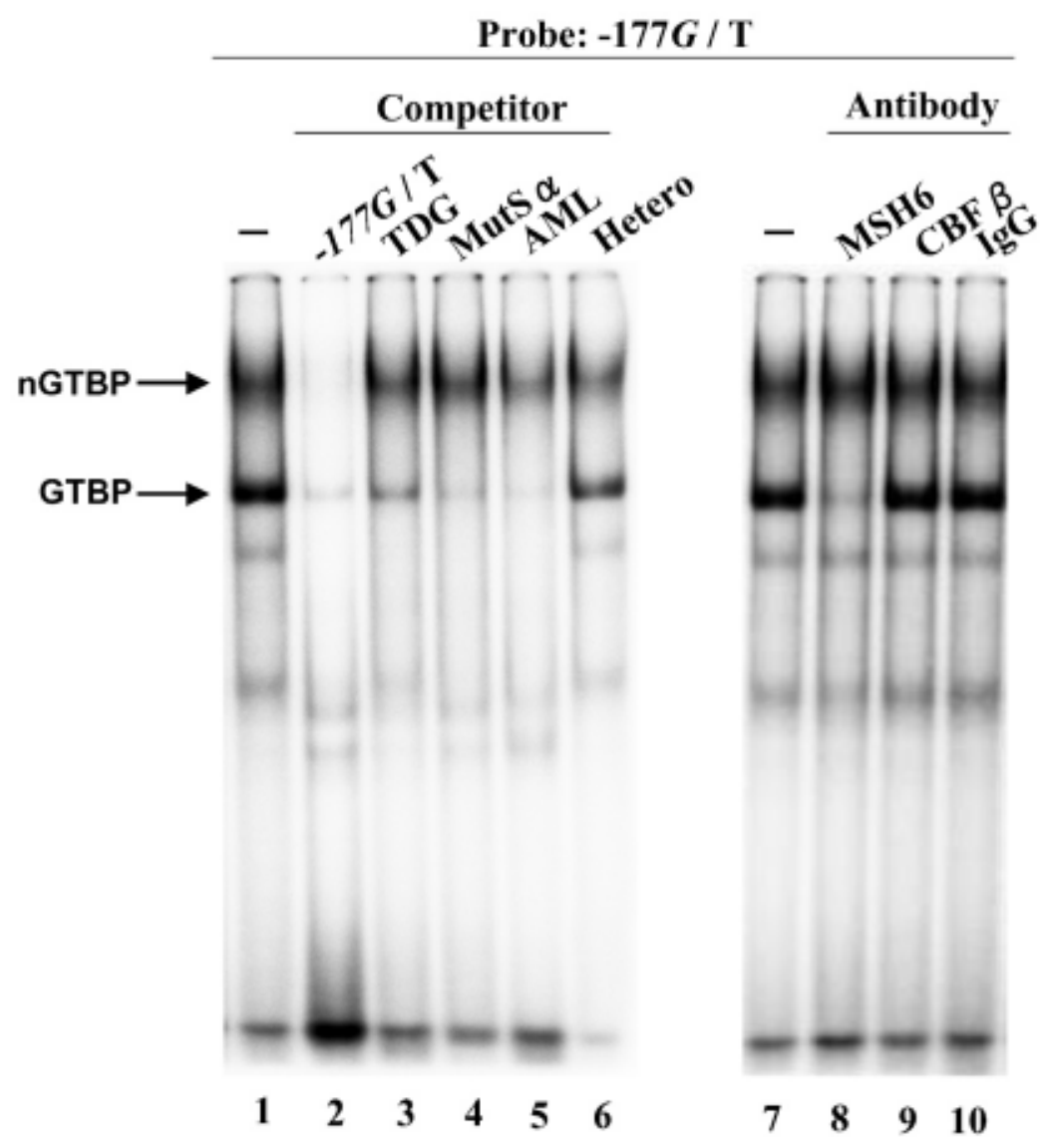

Fig. 5. nGTBP is different from TDG, hMutS $\alpha$ (hMSH2/hMSH6), and CBF (AML-1 $\alpha$ ) in binding site specificity and immunogenicity. EMSA was performed using $-177 \mathrm{G} / \mathrm{T} 23$-mer heteroduplex as the probe in the absence of poly $\mathrm{dI} / \mathrm{dC}$ to clearly demonstrate hMutS $\alpha$ (lower arrow, GTBP). The nGTBP band (nGTBP, upper arrow) was not abrogated by following competitors; TDG site oligomer (TDG, lane 3), MutS $\alpha$ site oligomer (MutS $\alpha$, lane 4), AML site oligomer (AML, lane 5), and a heterogenous homoduplex (Hetero, lane 6) with a sequence unrelated to that of the probe. Neither an antibody against MSH6 of $\mathrm{hMutS} \alpha$ (MSH6, lane 8) nor an antibody against $\mathrm{CBF} \beta$-subunit (CBF $\beta$, lane 9) affected the nGTBP band intensity. Control rabbit IgG (IgG, lane 10) was used as a negative control. 
tion, the nonspecific competitor-free condition was expected to permit the demonstration of a TDG-dependent shifted band (Neddermann and Jiricny 1994) if TDG could bind to the $-177 \mathrm{G} /$ T23-mer probe. TDG site consensus competitor heteroduplex (Fig. 5, competitor TDG), however, failed to compete with the probe for binding to nGTBP (line 3), indicating that nGTBP is different from TDG. MBD4, a member of the methyl $\mathrm{CpG}$ domain-binding protein family, can also bind to a G/T-mismatched pair and excise $\mathrm{T}$ from the pair (Hendrich et al. 1999), and was expected to be a candidate for nGTBP. However, it may preferably bind to the CpGcontaining TDG site competitor rather than the $-177 \mathrm{G} / \mathrm{T}$ probe, resulting in inhibition by the TDG-site competitor of the nGTBP band. This was not the case (lane 3). Accordingly, we conceive that nGTBP is a truly novel GTmismatch binding protein.

$n G T B P$ requires 14-mer or longer heterodupulex with a $G / T$ at a particular position

In order to define the minimal size of the heteroduplex for binding of nGTBP, duplexes serially truncated by 3 bp unit in the original $-177 \mathrm{G} / \mathrm{T}$ 23-mer heteroduplex from its upstream site (iU, i as depleted bp numbers) or downstream site (iD) were used as probes for EMSA (Fig. 6). The nGTBP band was not

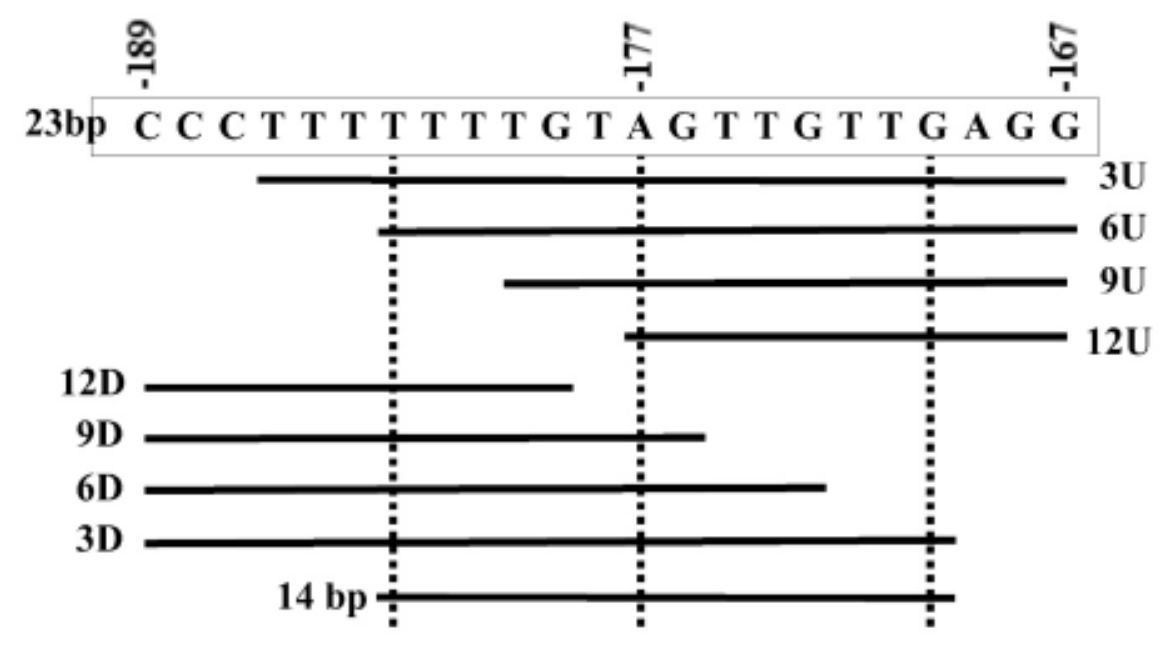

\section{Probe}

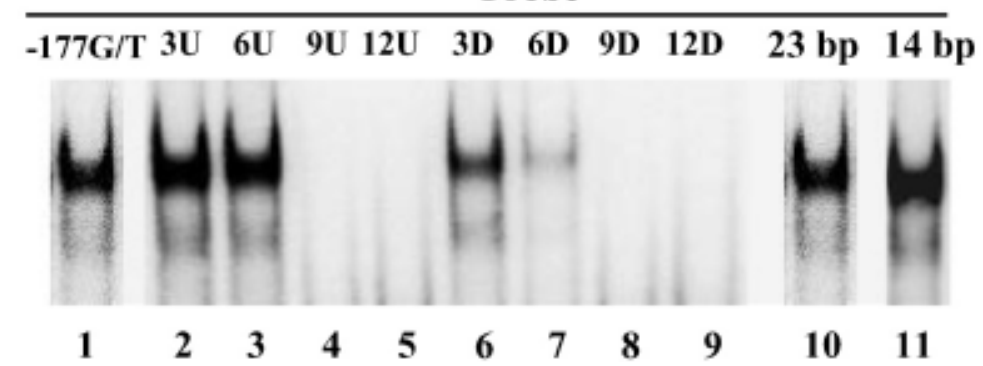

Fig. 6. nGTBP minimally requires a 14-mer heteroduplex for binding. -177G/T 23-mer heteroduplex was serially truncated three base pairs each either from the $5^{\prime}$-end (3U-12U) or the $3^{\prime}$-end (12D-3D) as illustrated. Truncation of the upper $6 \mathrm{bp}(6 \mathrm{U}$, lane 3$)$ or lower $3 \mathrm{bp}$ (3D, lane 6) does not inhibit the binding of nGTBP. Further cutting decreases the binding (see lanes 4, 5, 7, 8 and 9). The 14-mer heteroduplex probe spanning from bp -183 to bp -170 of gp91 phox promoter (14 bp, lane 11) exhibits nGTBP band, the intensity of which is comparable to the bands of the original $-177 \mathrm{G} / \mathrm{T} 23$-mer probe $(-177 \mathrm{G} / \mathrm{T}$ and $23 \mathrm{bp}$, lanes 1 and 10$)$. 
a

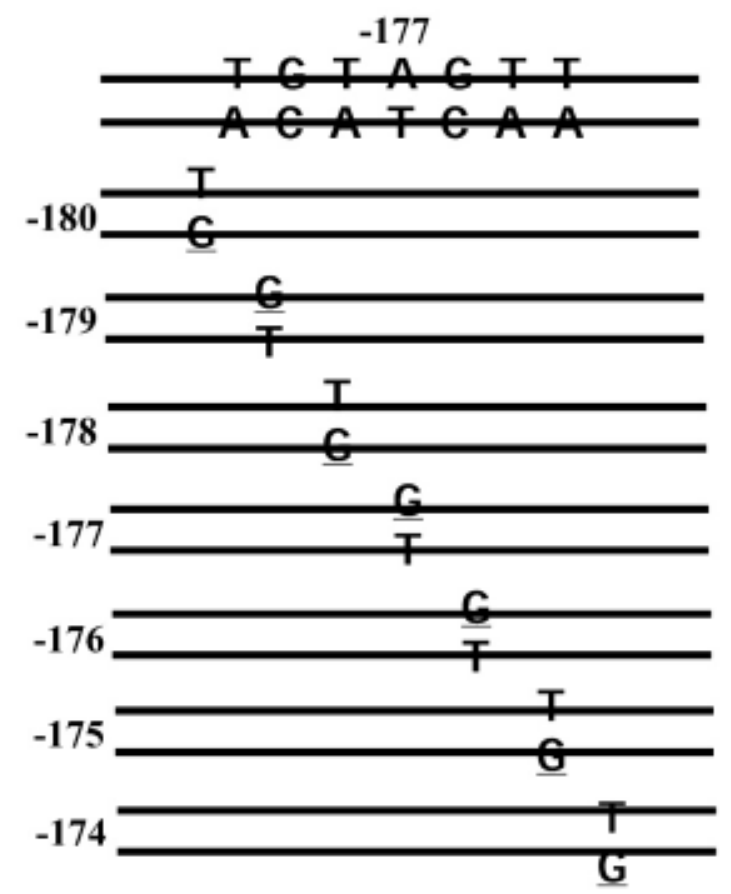

b

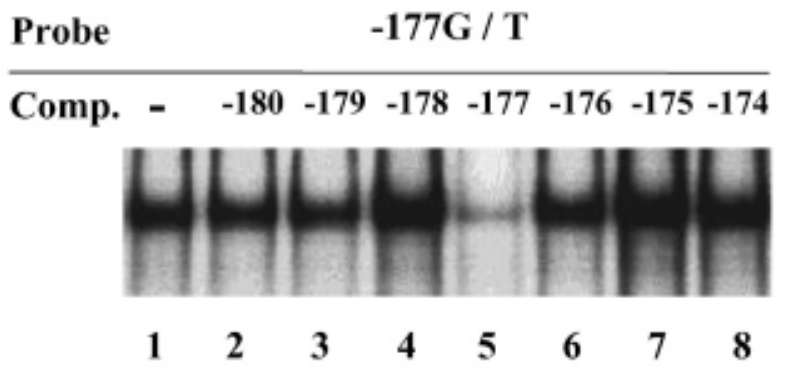

Fig. 7. A mismatched $\mathrm{G} / \mathrm{T}$ should be located at bp -177 . A G/T or $\mathrm{T} / \mathrm{G}$ mismatched pair was introduced to the wild-type 23-mer homoduplex as shown in (a), and each heteroduplex was used as a competitor in EMSA where the -177G/T 23-mer heteroduplex was used as a probe(b). Only the $-177 \mathrm{G} / \mathrm{T}$ competitor inhibits the $\mathrm{nGTBP}$ binding to the probe (lane 5).

demonstrated when upstream 9 bp were deleted (lane 4) and was hardly demonstrated when the downstream 6 bp were deleted (lane 7). Therefore a 14-mer heteroduplex spanning from bp -183 to bp -170 is minimally required for the binding of the nGTBP. This minimal 14-mer fragment (14 bp) could recruit nGTBP to the same extent as did the corresponding 23-mer heteroduplex (23 bp) (Fig. 6, lanes 10 and 11), suggesting the minimal fragment to be sufficient for full binding of nGTBP. Positional specificity of the $\mathrm{G} / \mathrm{T}$ mismatched pair was examined by introducing single $\mathrm{G} / \mathrm{T}$ or $\mathrm{T} / \mathrm{G}$ mismatches to the middle segment of the 23-mer competitor as shown in Fig. 7a. In contrast to the $-177 \mathrm{G} / \mathrm{T}$ 23-mer heteroduplex competitor (Fig. 7b, lane 5), none of other six competitors inhibited the binding of nGTBP to the $-177 \mathrm{G}$ / $\mathrm{T}$ mismatched probe (lanes $2-4,6-8$ ), indicating that a G/T mismatch should be located at bp
$-177$

A TRTGNB element is required for $n G T B P$ binding

We next analyzed base specificities around the $\mathrm{bp}-177 \mathrm{G} / \mathrm{T}$. We changed two TT units of the upstream T-rich region of the $-177 \mathrm{G} / \mathrm{T}$ 23-mer to GG units as shown in Fig. 8a (Dt-1 and Dt-2), and used these 23-mer fragments as competitors (Fig. $8 \mathrm{~b}$ ) or probes (Fig. $8 \mathrm{c}$ ). The nGTBP band exhibited by the original 23-mer heteroduplex probe (Fig. 8b, lane 1) was not abolished by the Dt-1 competitor (lane 3) but was abolished by Dt-2 competitor (lane 4) as done by the original heteroduplex competitor (lane 2). On the other hand, the Dt-2 probe (Fig. $8 \mathrm{c}$, lane 5) but not the Dt-1 probe (lane 3) exhibited a significant band that was competed with unlabeled probe sequence (lane 6). Therefore, either one or both of the last two $\mathrm{T}$ of the T-rich 
a

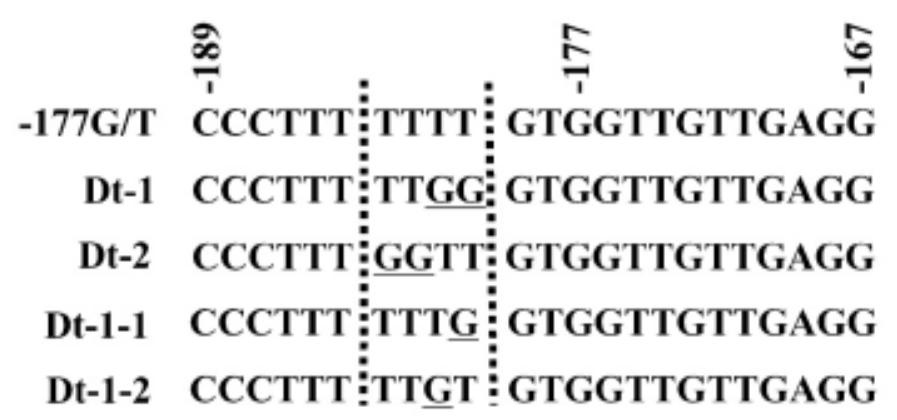

b

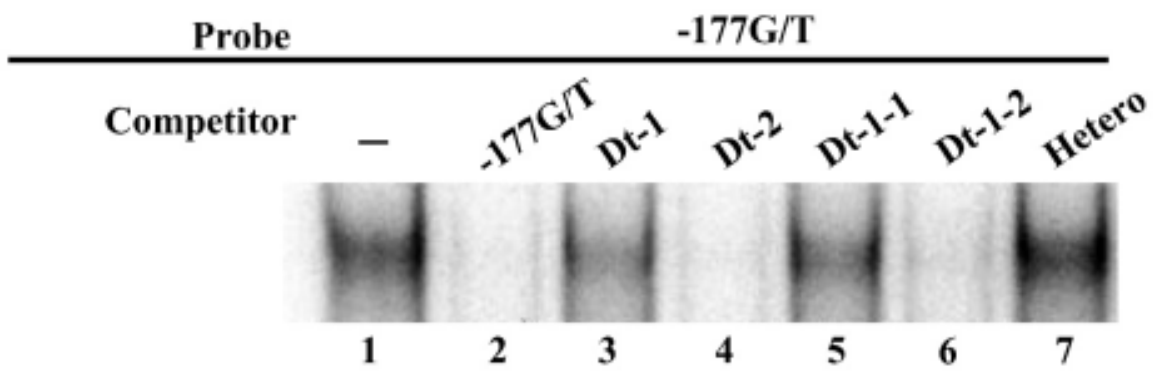

$\mathrm{c}$

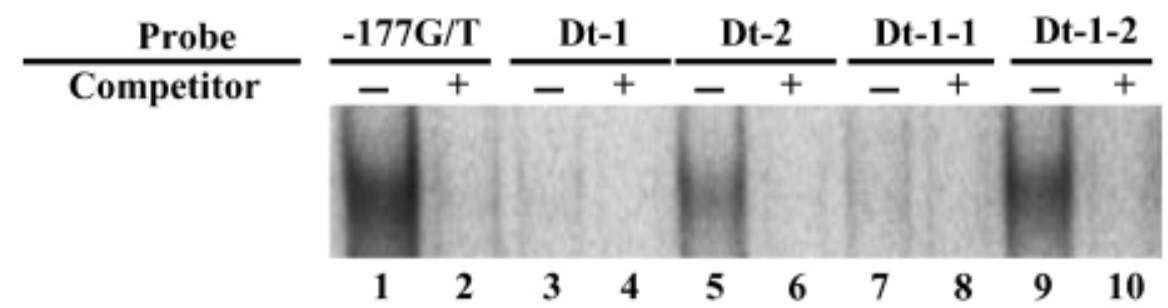

Fig. 8. Bp $-180 \mathrm{~T} / \mathrm{A}$ in the $-177 \mathrm{G} / \mathrm{T} 23$-mer probe is strict for nGTBP binding. (a) Upper strand sequences of the original $-177 \mathrm{G} / \mathrm{T} 23$-mer heteroduplex $(-177 \mathrm{G} / \mathrm{T})$ and its mutant heteroduplexes. Two sets of TT of original $-177 \mathrm{G} / \mathrm{T}$ were individually mutated to GG in probes Dt-1 and Dt-2, and mutated G of Dt-1 was one each reverted to T to make Dt-1-1 and Dt-1-2. (b) Competitions of the original $-177 \mathrm{G} / \mathrm{T} 23$-mer heteroduplex, its mutant heteroduplexes, and nonspecific heterogenous homoduplex (Hetero) against the $-177 \mathrm{G} / \mathrm{T}$ 23-mer probe on EMSA. In contrast to original -177G/T 23-mer heteroduplex (lane 2), Dt-1 and Dt-1-1 heteroduplexes cannot compete with the probe (lanes 3 and 5) for making nGTBP band. (c) EMSA for the demonstration of nGTBP band using various probes specified in (a) in the presence $(+)$ or absence $(-)$ of corresponding unlabeled probe competitors. Dt-2 and Dt-1-2 probes can demonstrate homologous competitor-sensitive nGTBP bands (lanes 5 and 9), suggesting bp $-180 \mathrm{~T} / \mathrm{A}$ to be important for nGTBP binding.

region are essential for the binding of nGTBP. Mutated two G of Dt-1 were individually reverted to T to make Dt-1-1 and Dt-1-2 (Fig. 8a). Dt-1-2 but not Dt-1-1 competed with the original 23-mer probe (Fig. 8b, lanes 5, 6), and the Dt-1-2 probe (Fig. 8c, lane 9), but not Dt-1-1 probe (lane 7), exhibited the nGTBP band as did the original one (Fig. $8 \mathrm{c}$, lane 1). Therefore, $\mathrm{T}$ at bp -180 cannot be substituted to $G$, but the other three upstream $\mathrm{T}$ can be substituted to $\mathrm{G}$. Further base specificities at bp -180 and its several downstream positions were determined using single-point-mutated 14-mer heteroduplex competitors (Fig. 9). The binding of the $-177 \mathrm{G} / \mathrm{T} 23$-mer to $\mathrm{nGTBP}$ was inhibited by the following single-point-mutated competitors; -179A (lane 6), -176A (lane 12), -176C (lane 13), -176T (lane 14), -175C (lane 16), 
Probe $-177 \mathrm{G} / \mathrm{T}$

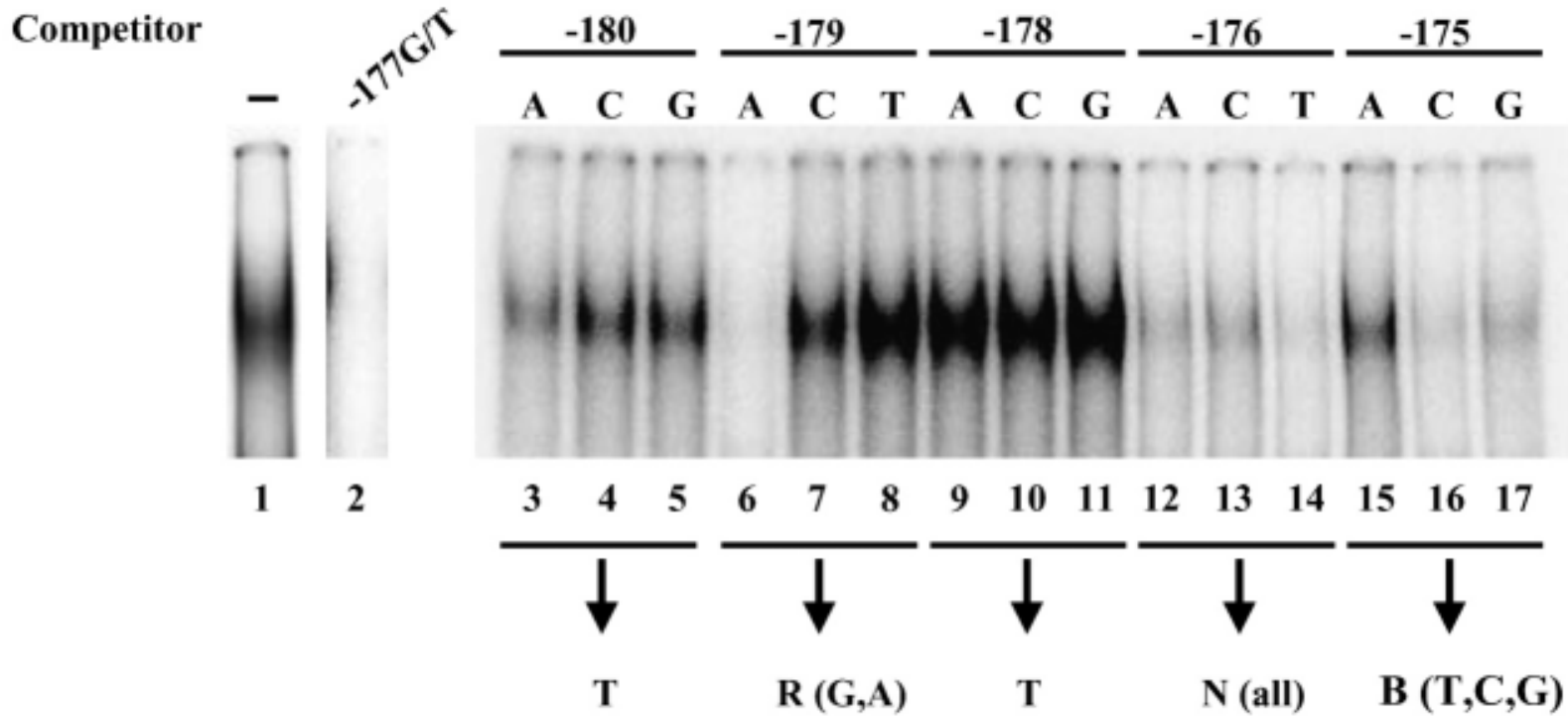

Fig. 9. Core base sequences of the upper strand of mismatched $-177 \mathrm{G} / \mathrm{T}$ heteroduplex are restricted to TRTGNB. Using -177G/T 23-mer heteroduplex as the probe, competitions by various 14-mer heteroduplexes were carried out using EMSA. Each competitor has mismatched $\mathrm{G} / \mathrm{T}$ at bp -177 and one substituted matched $\mathrm{bp}$, an upper strand base of which at the specified position (second line) is abbreviated by a single capital (thrid line) in the figure.

and -175G (lane 17). Therefore the core upper strand sequence for the nGTBP binding was concluded to be TRT GNB with the italicized G mismatched with $\mathrm{T}$. This sequence was not found in probes, with an exceptoin, for a GTmismatch binding reaction of mammalian cell nuclear extracts (Griffin and Karran 1993) and substrates for hMSH6 (Iaccarino et al. 1998), a human MutY homolog (hMYH) (Takao et al. 1999), a functional human MutM homolog (hOGG1) (Rosenquist et al. 1997), a human Nth ortholog (hNTH1) (Miyabe et al. 2002; Marenstein et al. 2003), a human MutM/Nei ortholog (hNEI1 or NEH1) (Bandaru et al. 2002; Hazra et al. 2002), and members of uracil-DNA glycosylase including UNG (Krokan et al. 2001), SMUG1 (Nilsen et al. 2001), TDG (Lari et al. 2002), and MBD4 (Hendrich et al. 1999). The only exception is the MPG protein but most of its target sequences are not in consensus with TRTGNB as mentioned later. We, therefore, conclude that this nGTBP is really a new
GT-binding protein.

nGTBP binds to a heteroduplex with high affinity

We next determined an apparent $\mathrm{Kd}$ for nGTBP to the $-177 \mathrm{G} / \mathrm{T}$ 23-mer heteroduplex by EMSA. An example of the EMSA data is shown in Fig. 10a, from which Scatchard plots were obtained (Fig. 10b). The plots gave an apparent $\mathrm{Kd}$ of $0.11 \mathrm{nM}$. Combined with two other independent results, we obtained 0.11 $( \pm 0.10) \mathrm{nM}$ as the apparent $\mathrm{Kd}( \pm 1$ S.D. $)$. This value was lower than the Kds reported for MutS $\alpha$ (2.6 nM; Iaccarino et al. 1998) and MPG protein (23.6 nM; Saparbaev et al. 2000) by at least one order of magnitude, suggesting that this nGTBP is specific to the above-mentioned mismatched core sequence and has some highly sensitive pathophysiological role in cells. 

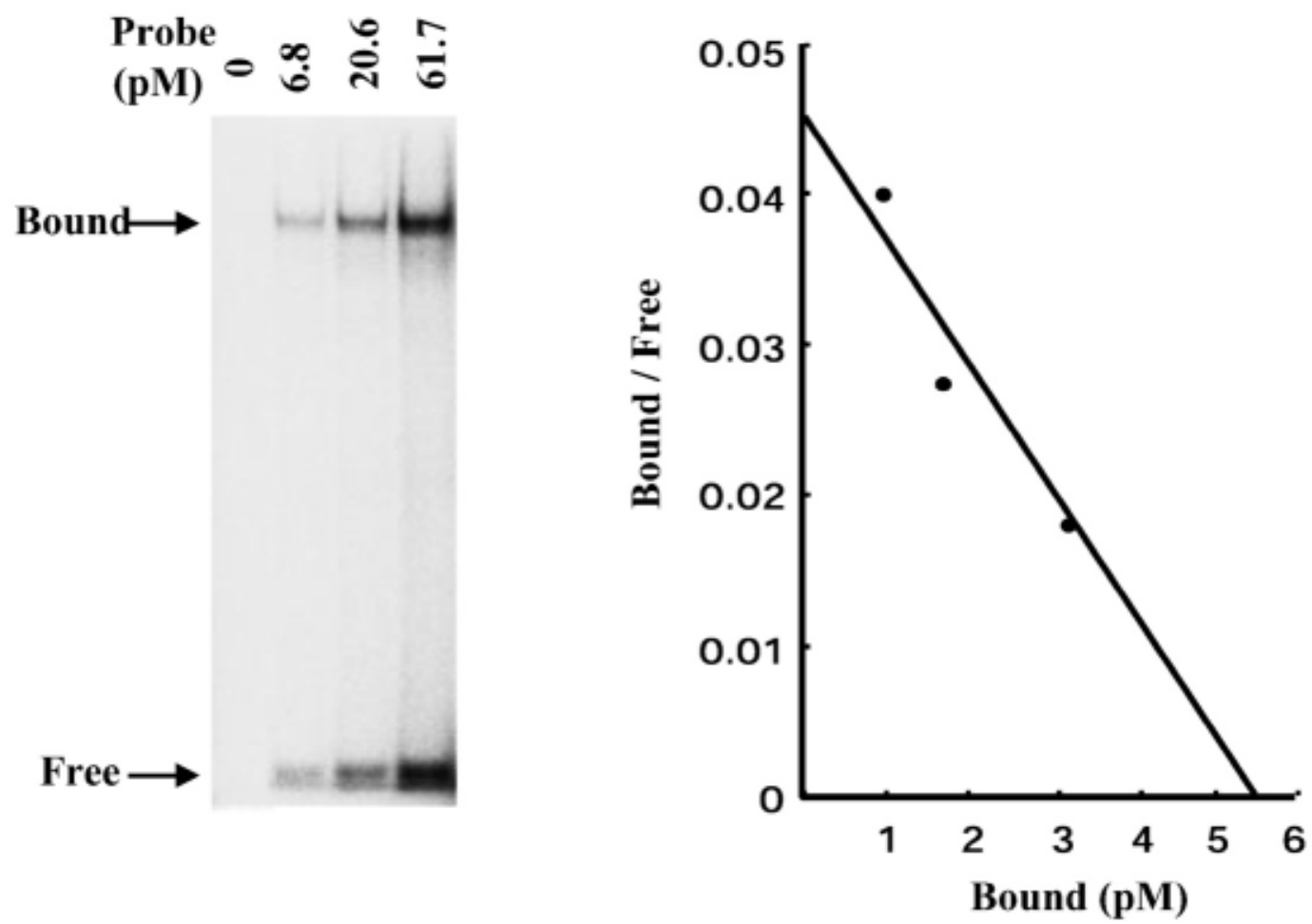

Fig. 10. Scatchard plots giving a high apparent dissociation constant (Kd). Different concentrations of $-177 \mathrm{G} / \mathrm{T}$ probe were mixed with a fixed amount of HL-60-C-15 nuclear extracts and subjected to EMSA (a), and its Scatchard plots are shown in (b), which has given $0.11 \mathrm{nM}$ as an apparent $\mathrm{Kd}$. The mean $\mathrm{Kd}$ ( \pm 1 s.D.) obtained from three independent experiments was $0.11( \pm 0.10) \mathrm{nM}$.

nGTBP weakly binds to duplex with a $G / U$ mismatch

In order to obtain some clues implying a pathophysiological role for the nGTBP, mostly in the repair of a non-replicating genome, we prepared several 14-mer "homoduplex" probes with modified bases at bp -177 derived from G/C or A/T (Fig. 11a), expecting some of these base pairs to mimic the mismatched $\mathrm{G} / \mathrm{T}$. The modified bases introduced to the "homoduplex" probes were oxidized $\mathrm{G}$ and $\mathrm{T}$ ( $\mathrm{oG}$ and $\mathrm{Tg}$ ), a 5-methylated $\mathrm{C}(\mathrm{mC})$, and deaminated $\mathrm{C}$ and $\mathrm{A}$ (uracil [U] and $\mathrm{Hx}$ ) (Fig. 12). In three G/Cderived 14-mer probes with $\mathrm{oG} / \mathrm{C}, \mathrm{G} / \mathrm{mC}$, and $\mathrm{G} / \mathrm{U}$ at bp -177 , the $\mathrm{G} / \mathrm{U}$ probe exhibited a weak but significant nGTBP band (Fig. 11a, lane 5), indicating that the mismatch-binding site of nGTBP can accept, to some extent, the $\mathrm{G} / \mathrm{U}$ pair possibly generated from $\mathrm{G} / \mathrm{C}$ by the deamination of $\mathrm{C}$ in DNA duplex or the incorporation of dUTP residue opposite to dGMP during DNA replication. G/mC "homoduplex" barely recruited nGTBP (lane 4) and competed in part with the $-177 \mathrm{G} / \mathrm{T}$ 23-mer probe at 300-times excess (data not shown), suggesting the nGTBP weakly recognizes $\mathrm{G} / \mathrm{mC}$. Weak binding of nGTBP to $\mathrm{G} / \mathrm{U}$ and $\mathrm{G} / \mathrm{mC}$ "homoduplexes" suggests that the DNA-binding site of nGTBP essentially requires both the absence of C-4 amino group and the presence of C-5 methyl group in the mismatch site G-pairing pyrimidine for its optimal binding to DNA duplex.

In probes with matched $\mathrm{A} / \mathrm{T}$-derived $\mathrm{Hx} /$ 
a

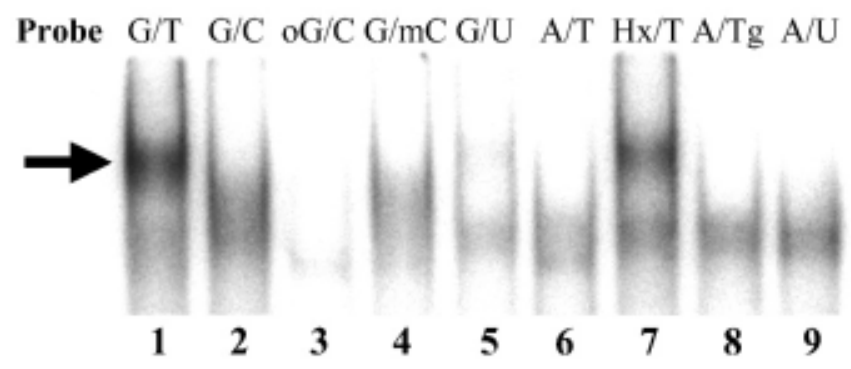

b

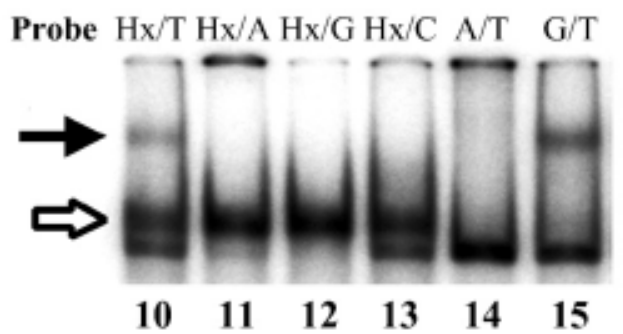

$\mathrm{c}$

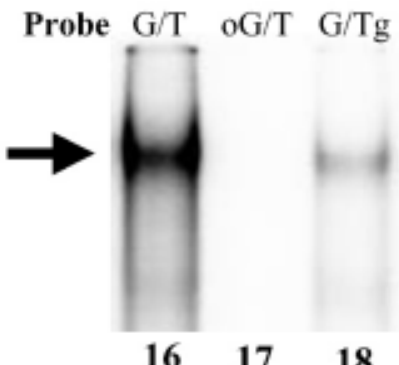

Fig. 11. Selective binding of nGTBP to DNA duplexes with modified base pairs at bp -177 . "Homoduplexes" with modified A/T or G/C (a), duplexes with $\mathrm{Hx} / \mathrm{N}(\mathrm{b})$, and "heteroduplexes" with modified mismatches (c) were used as probes. To each 14-mer duplex probe for EMSA, a modified base was introduced to bp -177 position as shown in the figure. Strength of significant nGTBP bands shown by a solid arrow is G/T (lane 1) $>\mathrm{Hx} / \mathrm{T}$ (lane 7) $\gg \mathrm{G} / \mathrm{U}$ (lane 5 ) $>\mathrm{G} / \mathrm{mC}$ (lane 4) in(a). Among $-177 \mathrm{Hx} / \mathrm{N}$ probes, $\mathrm{Hx} / \mathrm{T}$ probe is the only probe exhibiting nGTBP band indicated by a solid arrow (b, lane 10). An open arrow indicates bands of probes possibly making a complex with MPG protein (see text). The "heteroduplex" with modified G/Tg at bp -177 weakly exhibits nGTBP band (c, lane 18). Abbreviations: oG, 8-oxoG; $\mathrm{mC}$, methylC; U, uracil; $\mathrm{Hx}$, hypoxanthine; Tg, thymine glycol.

$\mathrm{T}, \mathrm{A} / \mathrm{Tg}$, and $\mathrm{A} / \mathrm{U}$, only the $\mathrm{Hx} / \mathrm{T}$ probe exhibited a significant band (Fig. 11a, lane 7), the intensity of which was comparable to that of the $\mathrm{G} / \mathrm{T}$ probe (lane 1 ). In agreement with these results, an $\mathrm{Hx} / \mathrm{T}$ competitor, but not $\mathrm{A} / \mathrm{Tg}$ and A/U competitors, inhibited the formation of the nGTBP band (data not shown). No probes with "mismatched" bases opposite to $\mathrm{Hx}$ exhibited a significant nGTBP band (Fig. 11b, lanes 11-13). Therefore, nGTBP recognizes $\mathrm{Hx}$ pairing only with $\mathrm{T}$. $\mathrm{Hx} / \mathrm{T}$ pairs are generated in double-stranded DNA by the deaminantion of $\mathrm{A}$ or by the incorporation of the residue of deaminated dATP, namely deoxyinosine triphosphate, into nascent DNA.
Because $\mathrm{U}$ and Hx correspond to deaminated C and -A, respectively (Fig. 12), our nGTBP is expected to preferentially recognize "matched" pairs lacking an exocyclic amino group attached to C-4 of pyrimidine or C- 6 of purine commonly involved in hydrogen bonds between bases (Fig. 12). "Homoduplex" with a typically oxidized oG/C pair and that with A/Tg pair are mainly recognized by human OGG1 (Aburatani et al. 1997), hNTH (Marenstein et al. 2003), and hNEI1 (Hazra et al. 2002). These homoduplexes, however, were not recognized by nGTBP (Fig. 11a, lanes 3 and 8), suggesting that nGTBP is little involved in the repair of the major adducts of oxidized bases. 


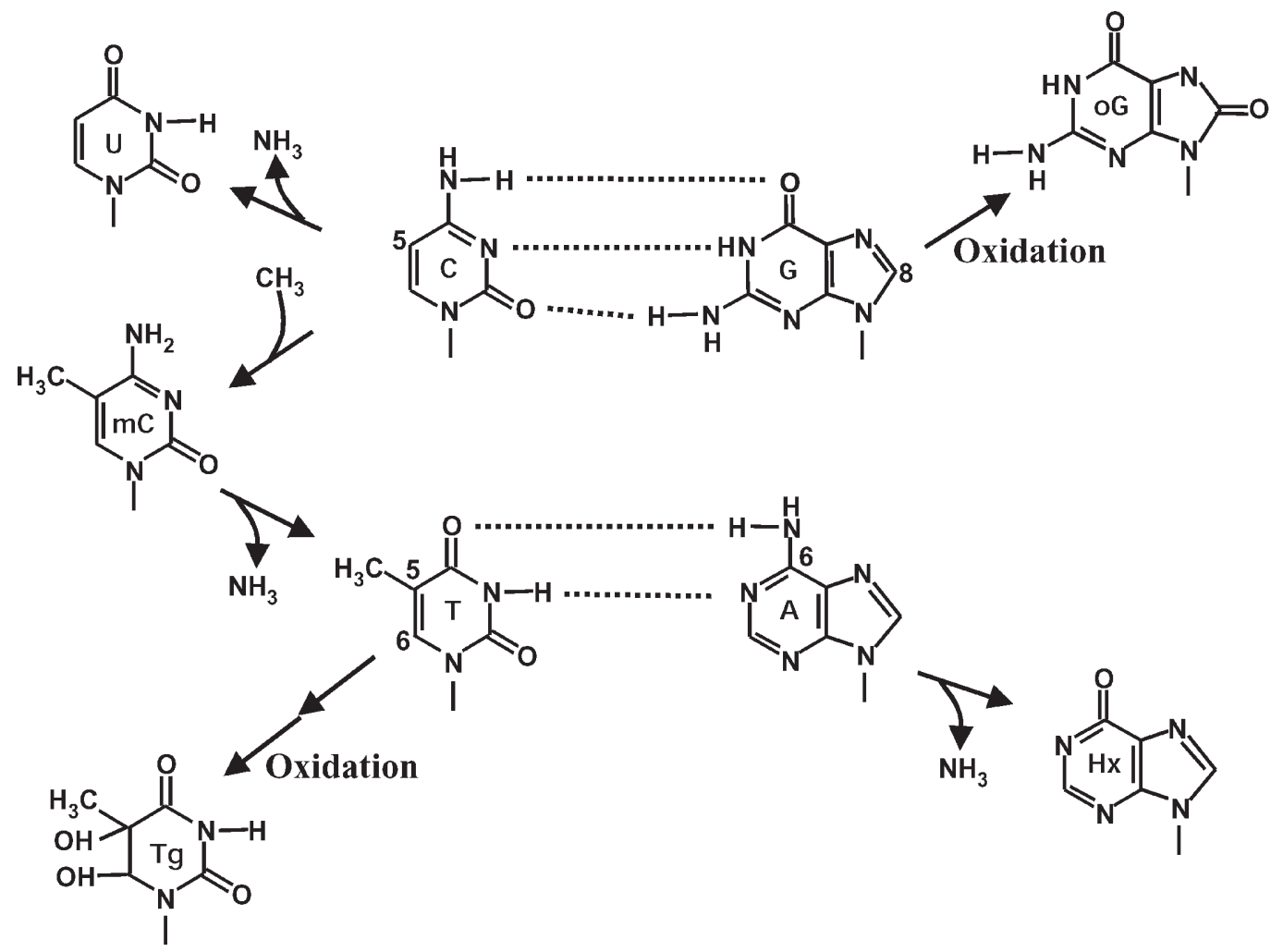

Fig. 12. Structures of intact DNA bases and their derivatives. See Fig. 11 and text for abbreviations put in cyclic structures.

Hx/T-containing DNA duplexes are good targets for the human MPG protein (Miao et al. 1998). Our nGTBP, however, would not be identical to the human MPG protein because of the following reasons: (1) The MPG protein binds not only to DNA with a TGTHxGG sequence (Vallur et al. 2002) matching to our consensus TRTRNB but also to DNA with other non-consensus sequences such as AAAHxCA and GGCHxGG (Miao et al. 2000). (2) The MPG protein recognizes duplexes with an $\mathrm{Hx}$ coupling with any bases (Saparbaev et al. 2000), which is consistent with newly appearing shifted bands demonstrated in Fig. 11b and indicated by an open arrow.

We introduced apurinic/apyrimidinic (AP) sites or deletions in this bp -177 of the wildtype 23-mer "homodulex" probe, or single nucleotide insertions to its neighbors. None of these probes exhibited a significant nGTBP band (data not shown), suggesting negligible roles of the nGTBP in insertion/deletion repair systems and the recognition of AP sites.

nGTBP weakly binds to a "heteroduplex"with a $G / T g$

In order to get some information about structural flexibility of the G/T mispair for nGTBP binding, we examined the structural diversity of the G/T pair for nGTBP binding (Fig. 11c). In the minimal 14-mer heteroduplex probes with an oG/T and G/Tg at bp -177 , only the latter probe exhibited a weak but significant nGTBP band (lane 18). Mismatched $\mathrm{G} / \mathrm{T}$ structure may be more distorted by the $5,6-\mathrm{OH}$ of $\mathrm{T}$ but remains tolerable for loose binding of nGTBP.

$\mathrm{G} / \mathrm{Tg}$ pair is hardly formed in the process of DNA synthesis because 2'-deoxyribonucleoside triphosphate of $\mathrm{Tg}$ is a poor substrate for the replication of DNA (Ide et al. 1987). It is, however, formed in static DNA by 
the oxidation and deamination of $\mathrm{mC}$ opposite $\mathrm{G}$, which is repaired by hNTH1 (Miyabe et al. 2002; Marenstein et al. 2003) and hNEI1 (Hazra et al. 2002). These endonucleases and $\mathrm{mC}$ forming DNA (cytosine-5)-methyltransferases are preferentially active on $\mathrm{CpG}$ sequences of DNA (Roy and Weissbach 1975), which are completely different from the consensus sequence of nGTBP.

No shifted bands by the oG/T probe (lane 17) and no inhibition of the nGTBP band by 300 times excess oG/T competitor (data not shown) suggest that nGTBP is different from the nuclear localizing type $2 \mathrm{hMYH}$, a human MutY homolog, having adenine (A/oG) DNA glycosylase activity (Takao et al. 1999). hMYH binds to and excises a heteroduplex with the core sequence of TCToGCA (Takao et al. 1999), which does not meet to TRTRNB, the core sequence for binding of nGTBP.

In summary, our nGTBP binds to minimal 14-mer duplexes with a TRTXNB element where the preferential order of the base pair at $\mathrm{X}$ is; $\mathrm{G} / \mathrm{T}>\mathrm{Hx} / \mathrm{T} \gg \mathrm{G} / \mathrm{U} \geqq \mathrm{G} / \mathrm{Tg}>\mathrm{G} / \mathrm{mC}$. All these results imply that an exocyclic aminogroup bonded to either pyrimidine $\mathrm{C}-4$ or purine C-6 should be absent and a methyl group should be attached to pyrimidine $\mathrm{C}-5$ for the binding of the nGTBP and that oxidized base pairs are not necessarily good targets of nGTBP.

nGTBP-recognizing $G($ or $H x) / T$ site may be transition-prone in human tumor protein $p 53$ coding sequence

In order to obtain some clues about the biological significance of nGTBP from the consensus TRTRNB sequence, we surveyed the p53 mutation database constructed by T. Soussi's group (Gallou et al. 2002) to find out if transition mutations occurred in the second $\mathrm{R}$ and its complementary pyrimidine sites. In 17 possible codons involved in the consensus TRTRNB sequences of the p53 exons, codon $146 \mathrm{tGg}(\mathrm{G}$ as the second R) for tryptophan and codon 239 $\operatorname{Aac}(\mathrm{A}$ as the second $\mathrm{R})$ for asparagine are the only codons usable for direct comparison of the same transitions in one codon resulting different stop codons or different amino acid substitutions; $\mathrm{t} A \mathrm{~g}$ for stop, $\mathrm{t} \mathrm{G} a$ for stop, $G \mathrm{ac}$ for aspartic acid, and $\mathrm{Agc}$ for serine (each transitioned base is italicized). The database contains 32 $\mathrm{t} A \mathrm{~g}+28 \mathrm{tG} a$ transitions at the TRTRNB consensus codon 146 in contrast to $6 \mathrm{t} A \mathrm{~g}+9 \mathrm{tG} a$ transitions in the remaining non-consensus $3 \mathrm{tGg}$ codons, in total. The database also contains 25 $\mathrm{Gac}+31 \mathrm{Agc}$ transitions at the consensus codon 239 in contrast to $10 \mathrm{Gac}+30 \mathrm{Agc}$ transitions in the remaining non-consensus 10 Aac codons, in total. These numbers are consistent with the assumption that the second $\mathrm{R}$ of the consensus TRTRNB position is transition-prone in the human p53 coding region.

We have presented an nGTBP which binds with high affinity to DNA duplexes containing a 5'-TRTG(or Hx)NB-3' sequence in which G or $\mathrm{Hx}$ is paired with $\mathrm{T}$, and is different from mismatch-binding proteins so far reported. Intact matched representative DNA sequence that can be modified to form this sequence for nGTBP binding is TRTRNB. Assuming that proportions of GC- and AT contents are 0.4 and 0.6 , respectively (Lander 2001), and bases are randomly distributed in these proportions, the representative TRTRNB sequence would be observed at 0.03 per one bp ( 2 strands $\times 0.6 / 2$ for $\mathrm{T}$ of the first position $\times 0.5$ for $\mathrm{R}$ of second position $\times 0.6 / 2$ for $T$ of third position $\times 0.5$ for $R$ of fourth position $\times 1$ for $\mathrm{N}$ of fifth position $\times$ [1-0.6/2] for $\mathrm{B}$ of last position). We actually found 17-, 29- and 107 sites in human p53 (1182 bp)-, gp91 ${ }^{\text {phox }}$ (1710 bp)-, and dystrophin (13 749 bp)-coding DNA sequences, respectively. The mean of these values was 0.013. We, therefore, roughly expect $10^{8}$ sites in a set of human diploid genome with $3 \mathrm{Gbp}$ (Lander 2001). Although no transition mutations at the second R position of TRTRNB sequence have been reported in the coding regions for gp91 ${ }^{\text {phox }}$ (Roos and Vihinen 2002) and dystrophin (HGMD Homepage 2003), six out of 1422 transition 
mutations were picked up from a database for human p53 (HGC p53 MDB Group of Human Genome Center 1997), some of which might have escaped from the surveillance of nGTBP. It should be noted that three promoter sites with possibly deamination-dependent mutations found in the human gp91 $1^{\text {phox }}$ promoter (C-55T, T-53C, and T-52C) (Suzuki et al. 1998) did not match with the consensus TRTRNB sequence.

Isolation of nGTBP and cloning of its cDNA are essential for elucidating its pathophysiological roles, and therefore, are now under investigation. Recently six new members of the MBD family were reported without any associated functional analysis (Roloff et al. 2003). Some of those newly reported MBD members might require neither methylated $\mathrm{C}$ nor $\mathrm{CpG}$ sites for binding. Furthermore, there might be a human homolog of $P a$-UDGb which was discovered in hyperthermophilic crenarchaeon Pyrobaculum aerophilum as the fifth member of UDG family (Sartori et al. 2002). This UDG can weakly bind to heteroduplexes with $\mathrm{G} / \mathrm{T}$ and recognizes modified DNA duplexes with $\mathrm{Hx} / \mathrm{T}$ and $\mathrm{G} / \mathrm{U}$, both abundantly emerge under hyperthermic conditions. It is interesting to determine whether our nGTBP is a member of the family or not. We expect the nGTBP to be involved in a repair system for protection against hydrolytic deamination of bases especially promoted by increased temperature conditions. In esophageal squamous carcinomas, the rate of GC-to/from-AT somatic transition occurring at the outside of $\mathrm{CpG}$ sequences of p53 exons is higher in southern Brazilian patients $(62 \%, 13$ out of 21 cases) than in world-wide patients $(30 \%)$, which might be explained, in part, by frequent exposure of esophagus to high temperature in the Brazilians because they have a habit to drink hot mate tea (Putz et al. 2002). So far, no transitions occurring at the second $\mathrm{R}$ site of the consensus TRTRNB sequence of their p53 exons have been reported.

\section{Acknowledgments}

We thank Dr. Mutsuo Sekiguchi (Fukuoka Dental College) and Dr. Takashi Shimada (Nippon Medical School) for valuable discussions and suggestions. We also thank Mr. Toshiyuki Moriuchi for his technical assistance and Drs. Shotaro Matsumoto, Taishi Nakagami, and Takuya Honda for their collaborative help. This work was supported in part by grants from the Ministry of Education, Science, Sports, and Culture of Japan and Aids for National Collaboration Research Projects of the Institute of Tropical Medicine.

\section{References}

Aburatani, H., Hippo, Y., Ishida, T., Takashima, R., Matsuba, C., Kodama, T., Takao, M., Yasui, A., Yamamoto, K. \& Asano, M. (1997) Cloning and characterization of mammalian 8-hydroxyguanine-specific DNA glycosylase/ apurinic, apyrimidinic lyase, a functional mutM homologue. Cancer Res., 57, 21512156.

Bandaru, V., Sunkara, S., Wallace, S.S. \& Bond, J.P. (2002) A novel human DNA glycosylase that removes oxidative DNA damage and is homologous to Escherichia coli endonuclease VIII. DNA Repair, 1, 517-529.

Burney, S., Caulfield, J.L., Niles, J.C., Wishnok, J.S. \& Tannenbaum, S.R. (1999) The chemistry of DNA damage from nitric oxide and peroxynitrite. Mutat. Res., 424, 37-49.

Cox, E.C., Degnen, G.E. \& Scheppe, M.L. (1972) Mutator gene studies in Escherichia coli: the mutS gene. Genetics, 72, 551-567.

Ehrlich, M., Norris, K.F., Wang, R.Y., Kuo, K.C. \& Gehrke, C.W. (1986) DNA cytosine methylation and heat-induced deamination. Biosci. Rep., 6, 387-393.

Gallou, C., Béroud, C. \& Soussi, T. (2001) ALL DB $12 / 2001$ at THE p53 DATABASE of DOWNLOAD OF THE p53 DATABASE in The p53 Database. http://p53.curie.fr/

Griffin, S. \& Karran, P. (1993) Incision at DNA G. $\mathrm{T}$ mispairs by extracts of mammalian cells occurs preferentially at cytosine methylation sites and is not targeted by a separate G.T binding reaction. Biochemistry, 32, 1303213039.

Hazra, T.K., Izumi, T., Boldogh, I., Imhoff, B., Kow, Y.W., Jaruga, P., Dizdaroglu, M. \& 
Mitra, S. (2002) Identification and characterization of a human DNA glycosylase for repair of modified bases in oxidatively damaged DNA. Proc. Natl. Acad. Sci. USA, 99, 3523-3528.

Hendrich, B., Hardeland, U., Ng, H.H., Jiricny, J. \& Bird, A. (1999) The thymine glycosylase MBD4 can bind to the product of deamination at methylated $\mathrm{CpG}$ sites. Nature, 401, 301304.

HGC p53 MDB Group of Human Genome Center (1997) p53 Mutation Database Search in p53 Mutation Database Analysis and Search. http://p53.genome.ad.jp/p53sch01.html

HGMD Homepage (2003) DMD: nucleotide substitutions (missense/nonsense). http://archive. uwcm.ac.uk/uwcm/mg/ns/1/119850.html

Iaccarino, I., Marra, G., Palombo, F. \& Jiricny, J. (1998) hMSH2 and hMSH6 play distinct roles in mismatch binding and contribute differently to the ATPase activity of hMutS $\alpha$. EMBO J., 17, 2677-2686.

Ide, H., Melamede, R.J. \& Wallace, S.S. (1987) Synthesis of dihydrothymidine and thymidine glycol 5 -triphosphates and their ability to serve as substrates for Escherichia coli DNA polymerase I. Biochemistry, 26, 964-969.

Karran, P. \& Lindahl, T. (1980) Hypoxanthine in deoxyribonucleic acid generation by heatinduced hydrolysis of adenine residues and release in free form by a deoxyribonucleic acid glycosylase from calf thymus. Biochemistry, 19, 6005-6011.

Kolodner, R. (1996) Biochemistry and genetics of eukaryotic mismatch repair. Genes Dev., 10, 1433-1442.

Kow, Y.W. (2002) Repair of deaminated bases in DNA. Free Radic. Biol. Med., 33, 886-893.

Krokan, H.E., Otterlei, M., Nilsen, H., Kavli, B., Skorpen, F., Andersen, S., Skjelbred, C., Akbari, M., Aas, P.A. \& Slupphaug, G. (2001) Properties and functions of human uracilDNA glycosylase from the UNG gene. Prog. Nucleic Acid Res. Mol. Biol., 68, 365-386.

Krokan, H.E., Drablos, F. \& Slupphaug, G. (2002) Uracil in DNA; occurrence, consequences and repair. Oncogene, 21, 8935-8948.

Lander, E.S. as the representative: International Human Genome Sequencing Consortium (2001) Initial sequencing and analysis of the human genome. Nature, 409, 860-921.

Lari, S.U., Al-Khodairy, F. \& Paterson, M.C. (2002)
Substrate specificity and sequence preference of $\mathrm{G}: \mathrm{T}$ mismatch repair: incision at $\mathrm{G}: \mathrm{T}$, O6-methylguanine: $\mathrm{T}$, and $\mathrm{G}: \mathrm{U}$ mispairs in DNA by human cell extracts. Biochemistry, 41, 9248-9255.

Leach, F.S., Nicolaides, N.C., Papadopoulos, N., Liu, B., Jen, J., Parsons, R., Peltomaki, P., Sistonen, P., Aaltonen, L.A., Nystroem-Lahti, M., Guan, X.-Y., Zhang, J., Meltzer, P.S., Yu, J.W., Kao, F.-T., Chen, D.J., Cerosaletti, K. M., Fournier, R.E.K., Todd, S., Lewis, T., Leach, R.J., Naylor, S.L., Weissenbach, J., Meklin, J.-P., Jaeruvinen, H., Petersen, G.M., Hamilton, S.R., Green, J., Jass, J., Watson, P., Lych, H.T., Trent, J.M., de la Chapelle, A., Kinzler, K.W. \& Vogelstein, B. (1993) Mutations of a mutS homolog in hereditary nonpolyposis colorectal cancer. Cell, 75, 1215-1225.

Lindahl, T. (1993) Instability and decay of the primary structure of DNA. Nature, 362, 709-715.

Lindahl, T. \& Wood, R.D. (1999) Quality control by DNA repair. Science, 286, 1897-1905.

Malkhosyan, S., McCarty, A., Sawai, H. \& Perucho, M. (1996) Differences in the spectrum of spontaneous mutations in the hprt gene between tumor cells of the microsatellite mutator phenotype. Mutat. Res., 316, 249-259.

Marenstein, D.R., Chan, M.K., Altamirano, A., Basu, A.K., Boorstein, R.J., Cunningham, R.P. \& Teebor, G.W. (2003) Substrate specificity of human endonuclease III (hNTH1). Effect of human APE1 on hNTH1 activity. J. Biol. Chem., 278, 9005-9012.

Marti, T.M., Kunz, C. \& Fleck, O. (2002) DNA mismatch repair and mutation avoidance pathways. J. Cell. Physiol., 191, 28-41.

Meyers, S., Downing, J.R. \& Hiebert, S.W. (1993) Identification of AML- 1 and the $(8 ; 21)$ translocation protein (AML-1/ETO) as sequencespecific DNA-binding proteins: the runt homology domain is required for DNA binding and protein-protein interactions. Mol. Cell. Biol., 13, 6336-6345.

Miao, F., Bouziane, M., Dammann, T.R. \& O'Connor, T.R. (1998) Interaction of the recombinant human methylpurine-DNA glycosylase (MPG protein) with oligodeoxyribonucleotides containing either hypoxanthine or abasic sites. Nucleic Acids Res., 26, 4034-4041.

Miao, F., Bouziane, M., Dammann, R., Masutani, C., Hanaoka, F., Pfeifer, G. \& O'Connor, T.R. 
(2000) 3-Methyladenine-DNA glycosylase (MPG protein) interacts with human RAD23 proteins. J. Biol. Chem., 275, 28433-28438.

Miyabe, I., Zhang, Q.M., Kino, K., Sugiyama, H., Takao, M., Yasui, A \& Yonei, S. (2002) Identification of 5-formyluracil DNA glycosylase activity of human hNTH1 protein. Nucleic Acids Res., 30, 3443-3448.

Mol, C.D., Arvai, A.S., Slupphaug, G., Kavli, B., Alseth, I., Krokan, H.E.\& Tainer, J.A. (1995) Crystal structure and mutational analysis of human uracil-DNA glycosylase: structural basis for specificity and catalysis. Cell, 80, 869-878.

Nakajima, E., Ikejima, M., Watanabe, A. \& Shimada, T. (1999) Identification of the protein components of mismatch binding complexes in human cells using a gel-shift assay. FEBS Lett., 453, 85-89.

Neddermann, P. \& Jiricny, J. (1994) Efficient removal of uracil from G.U mispairs by the mismatch-specific thymine DNA glycosylase from HeLa cells. Proc. Natl. Acad. Sci. USA, 91, 1642-1646.

Neddermann, P., Gallinari, P., Lettieri, T., Schmid, D., Truong, O., Hsuan, J.J., Wiebauer, K. \& Jiricny, J. (1996) Cloning and expression of human G/T mismatch-specific thymine-DNA glycosylase. J. Biol. Chem., 271, 12767-12774.

Nilsen, H., Haushalter, K.A., Robins, P., Barnes, D.E., Verdine, G.L. \& Lindahl, T. (2001) Excision of deaminated cytosine from the vertebrate genome: role of the SMUG1 uracil-DNA glycosylase. EMBO J., 20, 4278-4286.

Petersen-Mahrt, S.K., Harris, R.S. \& Neuberger, M.S. (2002) AID mutates E. coli suggesting a DNA deamination mechanism for antibody diversification. Nature, 418, 99-103.

Putz, A., Hartmann, A.A., Fontes, P.R., Alexandre, C. O., Silveira, D.A., Klug, S.J. \& Rabes, H.M. (2002) TP53 mutation pattern of esophageal squamous cell carcinomas in a high risk area (Southern Brazil): role of life style factors. Int. J. Cancer, 98, 99-105.

Reanney, D.C. \& Pressing, J. (1984) Temperature as a determinative factor in the evolution of genetic systems. J. Mol. Evol., 21, 72-75.

Roloff, T.C., Ropers, H.H. \& Nuber, U.A. (2003) Comparative study of methyl-CpG-binding domain proteins. BMC Genomics, 4, 1.

Roos, D. \& Vihinen, M. (2002) CYBB base: Muta- tion registry for $\mathrm{x}$-linked chronic granulomatous disease. http://www.uta.fi/ imt/bioinfo/CYBBbase/

Rosenquist, T.A., Zharkov, D.O. \& Grollman, A.P. (1997) Cloning and characterization of an 8-oxoguanine DNA glycosylase. Proc. Natl. Acad. Sci. USA, 94, 7429-7434.

Roy, P.H. \& Weissbach, A. (1975) DNA methylase from HeLa cell nuclei. Nucleic Acids Res., 2, 1669-1684.

Saparbaev, M., Mani, J.C. \& Laval, J. (2000) Interactions of the human, rat, Saccharomyces cerevisiae and Escherichia coli 3-methyladenineDNA glycosylases with DNA containing dIMP residues. Nucleic Acids Res., 28, 13321339.

Sartori, A.A, Fitz-Gibbon, S., Yang, H., Miller, J.H. \& Jiricny, J. (2002) A novel uracil-DNA glycosylase with broad substrate specificity and an unusual active site. EMBO J., 21, 3182-3191.

Singer, B. \& Hang, B. (2000) Nucleic acid sequence and repair: role of adduct, neighbor bases and enzyme specificity. Carcinogenesis, 21, 10711078.

Suzuki, S., Kumatori, A., Haagen, I.A., Fujii, Y., Sadat, M.A., Hao, J.L., Tsuji, Y., Roos, D. \& Nakamura, M. (1998) PU.1 as an essential activator for the expression of gp91 ${ }^{\text {phox }}$ gene in human peripheral neutrophils, monocytes, and B lymphocytes. Proc. Natl. Acad. Sci. USA, 95, 6085-6090.

Takao, M., Zhang, Q.M., Yonei, S. \& Yasui, A. (1999) Differential subcellular localization of human MutY homolog (hMYH) and the functional activity of adenine: 8-oxoguanine DNA glycosylase. Nucleic Acids Res., 27, 36383644.

Vallur, A.C., Feller, J.A, Abner, C.W., Tran, R.K. \& Bloom, L.B. (2002) Effects of hydrogen bonding within a damaged base pair on the activity of wild type and DNA-intercalating mutants of human alkyladenine DNA glycosylase. J. Biol. Chem., 277, 31673-31678.

Yang, D., Suzuki, S., Hao, L.J., Fujii, Y., Yamauchi, A., Yamamoto, M., Nakamura, M. \& Kumatori, A. (2000) Eosinophil-specific regulation of gp91 ${ }^{\text {phox }}$ gene expression by transcription factors GATA-1 and GATA-2. J. Biol. Chem., 275, 9425-9432.

Waters, T.R., Gallinari, P., Jiricny, J. \& Swann, P.F. (1999) Human thymine DNA glycosylase 
binds to apurinic sites in DNA but is displaced by human apurinic endonuclease 1 . J. Biol.

Chem., 274, 67-74. 